\title{
The Role of Parents in Monitoring the Negative Impacts of Gadget Usage for Early Childhood during Covid-19 Pandemic Era
}

\author{
Arini Cahyani ${ }^{1,{ }^{*}}$ Ketut Atmaja ${ }^{1}$ Widodo $^{1}$ \\ ${ }^{1}$ Pendidikan Luar Sekolah, Universitas Negeri Surabaya \\ "Corresponding author. Email: arini.20001@mhs.unesa.ac.id
}

\begin{abstract}
The use of gadgets without parental assistance has a negative impact on children. This study aims to describe the role of parents in the negative impact of using gadgets for early childhood during the Covid-19 pandemic. This study uses a descriptive approach with the research subject of Kuncup Harapan Playgroup educators and parents. Data collection techniques using structured interviews and documentation. Data analysis technique using Miles and Huberman. The study results indicate that parental assistance in the use of gadgets for early childhood is essential to avoid negative impacts that affect children's development. There is a motive for parents to give gadgets, namely because of motives and In Order Motives. Then the way for parents of the Kuncup Harapan Playgroup in assisting children using gadgets, among others, when children use gadgets, selecting safe content according to the child's age, using gadgets with children's activities, setting rules for using gadgets and parenting is essential with the times. The form of parenting activities for Kuncup Harapan playgroup during the Covid-19 pandemic, namely involvement in learning at home, communication, volunteering, and decisionmaking for children's education, as well as providing parents with digital literacy to reduce the negative impact of using gadgets through the e-parenting application.
\end{abstract}

Keywords: Gadgets, Early childhood, Parents, Covid-19 pandemic

\section{INTRODUCTION}

Since the beginning of 2020, the whole world has experienced non-natural disasters caused by a type of Coronavirus or severe acute syndrome coronavirus (SARS-CoV-2) or better known as Covid-19 [1]. This virus was first discovered in Wuhan, China's Hubei Province. The spread of Covid-19 is so speedy that it has spread throughout the world, including Indonesia. The number of people infected with Covid-19 in Indonesia increases every day; on March 30, 2021, there were 1,505,775 [2] infected with Covid-19. It has been more than a year since humans around the world have adapted to Covid-19. This has resulted in several public services that are still limited in interacting because the spread of Covid-19 can be through human interaction [3]. One alternative so that humans can interact with the environment, namely utilizing technology. The use of technology in gadgets during the Covid-19 pandemic is very much needed because human activities can continue through this. With the influence of globalization, humans in situations of limitations can be helped in all fields without stopping their usual activities. So an update or self-renewal is needed so as not to be left behind from the flow of globalization during the Covid-19 pandemic.
During the Covid-19 pandemic, the community experienced extraordinary impacts that affected health, economic, social, worship, and other aspects for approximately one year. In terms of public health, most of them have been exposed to Covid-19, which requires self-isolation [4]. In addition, the number of deaths due to Covid-19 is increasing every day, so the government makes policies by limiting people's activities outside. These limitations make most people lose their jobs and bankruptcy. As a result, the economy has decreased, which impacts people's welfare [5]. In addition, public services such as schools were also closed. With these limitations, technology is constructive for workers, business actors, and students by carrying out activities through online media [6]. Self-renewal adaptation is needed to continue to survive in conditions of limitations [6]. Self-renewal is very much needed because humans cannot be separated from the influence of globalization, especially in a pandemic. One form of globalization that affects changes in human life is extraordinary, namely technology [7]. Technology was created to facilitate all human activities, both in public services such as health, education, administration, security, and so on; besides making production more straightforward, it even facilitates household activities [8]. The important role of 
technology today is to bring human civilization into the era of the industrial revolution 4.0 [9]. Schlechtendahl defines the era of the industrial revolution 4.0, which is a transformation in the speed of availability of information that is incorporated and able to share information from one another [10].

One form of technology that is in great demand and practical in its use is gadgets. Gadgets are one of the technologies that provide convenience for many people. The wide world of the internet can make it easier for users to access the desired content. Internet users are not only for adults, children and even young children to participate [11]. Gadgets provide the latest feature services, both in accessing information or facilitating human activities [12]. In the past, gadgets were very expensive goods and users were limited to only certain circles, such as the upper class and office business people, but now at affordable prices, the lower class can also buy them, so it is not surprising that parents buy gadgets specifically for children. The sophistication and convenience provided by gadgets cause children and even early childhood to be active users of gadgets, especially smartphones [13]. Their reasons for using gadgets, namely as entertainment, include playing games, watching videos, listening to music, etc. According to the results of Sahriana's research [14], it was found that most children can access videos on YouTube even though they are not yet able to read, but they can recognize symbols or images from the application. Thus, according to previous research, $42.1 \%$ of early childhood gadget users are more dominant in playing games and watching videos [15].

Childhood, especially early childhood, is an early stage in human life. At the beginning of life for early childhood, its development is very complex, which can make the main foothold in later life, such as adolescence and adulthood [16]. Complex development in early childhood requires a stimulus to the optimal point in accordance with age. Because the basis of human ability is formed from an early age, starting from walking, eating, talking, etc. Naturally, early childhood will learn what is around them. Therefore children's behaviour is formed from the daily examples of parents at home because, in fact, early childhood is an excellent imitator who easily imitates what is seen and heard [17]. Early childhood begins to learn things in the surrounding environment through experiences gained from those closest to them so that with this, children can learn to know about life. Thus, everything related to child development requires the perfect combination of genetic and environmental factors that make it a stimulus for children to have the best learning experience [18].

Early childhood life is currently strongly influenced by digital technology, which makes that child development cannot be equated with previous early childhood experiences. It is necessary to adjust aspects of child development with technology, such as children's toys, relationships with parents, and the surrounding environment. It is important to consider the use of gadgets in parenting in today's modern era and behaviour in participating in using gadgets. Findings related to the dangers and consequences of using gadgets, namely that children can be at risk materially in the form of images that are not suitable for the child's age, they also result in poor communication between children and those around them, as well as children's actions that are considered to be detrimental to others, such as defamation [19]. In addition, the use of gadgets without realizing it makes users experience dependence, even for young children. This dependence is a negative impact of using gadgets [20]. If they are not given a gadget, many children get angry or have tantrums to hurt themselves and others. So this can encourage parents to balance the benefits and harms of using gadgets for children. Parental assistance is needed for children in using gadgets.

The family is the first place for children to get an education [3]: the closest people, namely parents, influence all children's activities. Children are a reflection of their parents. Therefore parents should be good role models for children (Rakhmawati). It should be reaffirmed that parents cannot simply give up on educating children because education in the family is a lifelong process that lasts throughout life so that each individual acquires values, knowledge, attitudes, and skills derived from the experience gained and is influenced by the environment, including the family. , neighbours, workplace, school, playground and mass media [21]. Thus, humans' first and foremost education comes from the family (informal) [22].

In the family, children are formed based on habits carried out by family members, especially parents. Parents find it difficult to educate their children in the current digital era because if they are too authoritarian, children will become aggressive and left unchecked, especially during the Covid-19 pandemic, where all children's activities occur at home [23]. Thus, it is necessary to have a way of parenting that is following the current digital era, which can be based on the theory of Albert Bandura [24], among others, live models, symbolic models, and verbal description models. 1) live model, i.e., parents become models for children, then good or bad parental behaviour can be reflected in children, because what children see and listen to children will imitate, especially for early childhood this happens. After all, at that age, children become imitators and think that parents' behaviour is the best example for children. 2) symbolic models, namely models derived from parables, such as picture 
stories, television shows, video games, etc. The role of parents here is to provide direction for children to choose shows that children will watch through gadgets. Limit it with a special child account that can be accessed with the limitations that have been set. Thus the child will not access things that are not ageappropriate. In addition, by being limited through a child-only account, parents can monitor their children for how many hours they use gadgets. 3) verbal description model, which is a model expressed in words or words. Parents provide direction to children through small discussions about what activities are carried out in one day, with this, parents can provide advice to make sense of life. For early childhood, which is the initial stage of life, a direction in the form of verbal form to children is needed to understand what someone is saying, especially parents, such as orders, advice, prohibitions, invitations and so on. This will form a disciplined and responsible child's personality.

It often happens that parents give gadgets to young children for certain reasons or motives. The use of gadgets for children depends on the parents who provide these facilities. According to Alfred Schutz [25] that there are motives that influence human actions, one of which is the decision of parents in providing gadgets for early childhood, namely 1) because to motive, the motive arises as a result of past experiences which is used as a driving force to determine one's actions. For example, parents had never owned a gadget before because the price at that time was still high. Only certain circles can have it; they assume that those who have gadgets are rich people. Nowadays, with low prices, parents do not want their children to be left behind in technology like their parents, who cannot understand the use of gadgets. So experiences can be a person's motive in making a decision or action. 2) In Order Motive, motive arises because there are values of taking action now for the future. For example, they were giving gadgets to children because there are values for their actions in giving gadgets for future goals or reach. Thus, parents need to pay attention to giving gadgets to children. During the current pandemic, the use of gadgets in children is very high, around $79 \%$ without parental assistance [26]. This is because children in the teaching and learning process use gadgets, and parents have no reason for children not to use gadgets. In addition, by always being at home, entertainment for children during the Covid-19 pandemic is only in the form of games available on gadgets. Therefore the role of parents to always accompany children in the use of gadgets is needed.

Parents must adapt to increasingly rapid technological developments because parents are the closest and protective people for children. Thus, the role of parents in assisting children in using gadgets is needed so that the negative impacts caused by gadgets can be anticipated with family education. There are ways for parents to assist early childhood in using gadgets, including [27], 1) Limit the time children use gadgets. Parents can limit the time their children use gadgets not to forget time for their inner needs, such as eating, studying, bathing, etc. By limiting time, children will not be addicted to their use, especially for early childhood, therefore do not often give gadgets when parents are busy in their activities. Use storybooks or educational game tools (APE) that are interesting for children as a substitute for gadgets. 2) Selection of safe content according to the age of the child. The selection of games, videos, images and audio is adjusted to the child's age-lots of content that is easily accessible through gadgets. So parents can choose and monitor their children by creating a special account for their children, which has already been filtered. Thus, a healthy spectacle makes children stimulate their development well. 3) Balance the use of gadgets with children's activities. Parental assistance is needed in balancing children in using gadgets and other activities. Parents often let their children play with their gadgets, so they do not go out of the house to play with their friends. Thus parents should be able to set a schedule, especially for early childhood. In addition, invite children in housework activities, such as entering, washing clothes, sweeping, watering flowers, etc. Therefore parents provide examples for children not to play with gadgets without time limits. 4) Set rules in the use of gadgets for children. The rules are given so that children can be disciplined in their responsibilities. The rules made are also implemented by parents, such as the time limit for using gadgets is 30 minutes, so parents use limited-use gadgets only to use them, 5) Parents need to adapt to the times. Parents need digital literacy to protect children from the dangers of using gadgets. Education for parents is needed either through books, gadgets, newspapers or magazines to add insight to parents. With this, parents can be technology literate to monitor their children's use of gadgets.

The research was conducted in the Kuncup Harapan Playgroup of Kota Baru Driyorejo Gresik. Researchers took this location because there were problems that occurred to parents during the Covid-19 pandemic; namely, children were dependent on using gadgets. According to the results of initial interviews with parents, children cannot be separated from gadgets. This is evidenced when waking up what they are looking for, namely gadgets, besides when there is a gathering of family or friends for certain events, the child is not as active as before, such as playing with peers but sitting and playing with gadgets. This makes parents feel afraid of their children using gadgets excessively, especially when they are not given the 
child will have a tantrum. This happens because activities at school have not been face-to-face for a year, resulting in a change in children's activity patterns. This change is due to both parents who are busy working due to the impact of the Covid-19 pandemic, whose mother used not to work and is now working. So that children do not cry when their parents work, gadgets are given. Therefore, it is necessary to assist parents in using gadgets in early childhood to balance children's physical activities.

Researchers found an interesting phenomenon in the Kuncup Harapan Playgroup. This institution provides intensive parenting services for parents during the Covid-19 pandemic in active communication via WhatsApp to make it easier for parents to teach their children while at home. In addition, the Kuncup Harapan Playgroup educator provides digital literacy to parents in the form of an eparenting application. It is hoped that parents will increase their knowledge during the Covid-19 pandemic about children. It is hoped that parents can always update information about parenting and make it easier to search with the application with reparenting. Then the e-parenting application is equipped with a video in the form of parenting information. Parents who are lazy in reading can watch videos to make it easier for parents to transfer knowledge. This innovation makes it easier for parents to know their children, especially during the Covid-19 pandemic. The e-parenting application is expected to form a collaboration between parents and educators of the Kuncup Harapan Playgroup, including involvement in learning at home, communication, and decision-making in children's education. Thus, the purpose of this study is to describe parental assistance in the use of gadgets for early childhood during the Covid-19 pandemic.

\section{RESEARCH METHODS}

This study uses a descriptive qualitative research approach. The research was conducted to describe the role of parents in supervising early childhood in the use of gadgets so as not to hinder the development and growth of children. The research location is in the Kuncup Harapan Playgroup Kota Baru Driyorejo Gresik. The research time is six months, starting from October 2, 2020 - March 3, 2021. This study uses a sampling technique carried out by purposive sampling, determining respondents based on certain criteria. In this study, they acted as research subjects, namely educators and parents with the following criteria and numbers, the parents of the Kuncup Harapan Playgroup of 12 people with the criteria of age 20-35, involved in assisting children in online learning for 12 months, minimum education high school, and parents who are active gadget users. Data collection techniques using primary and secondary data. Primary data was obtained from structured interviews conducted online using "What's App" and secondary data in the form of documents regarding the identity of educators, students, parents.

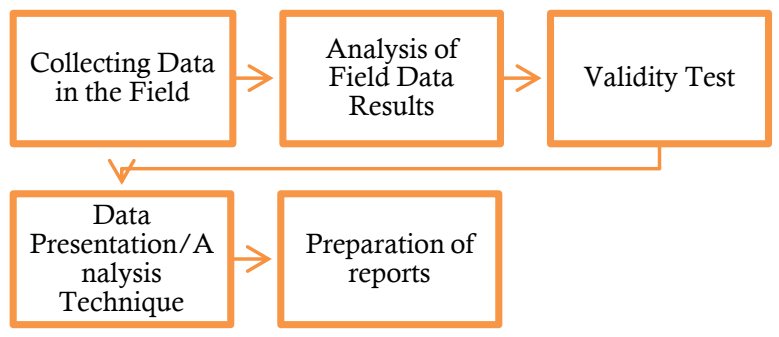

Figure 1 Research flow

The data validity technique used in this study is the triangulation technique. The triangulation technique is defined as a collection technique from existing data sources. Furthermore, the data analysis technique used Miles and Huberman analysis. Miles and Huberman, namely data analysis is carried out interactively and continues continuously until the data is saturated, then in data analysis activities, namely data reduction, data display, and conclusion.

\section{RESULTS AND DISCUSSION}

The research was carried out in the Kuncup Harapan Playgroup of Kota Baru Driyorejo Gresik. The research was carried out for six months, starting from October 2, 2020 - March 3, 2021. This study aims to describe parental assistance in using gadgets for early childhood during the Covid-19 pandemic. The focus of the research is, among others, the motives or reasons for parents giving gadgets to early childhood and assisting parents in using gadgets for early childhood during the Covid-19 pandemic.

\subsection{Parents' Motives for Giving Gadgets to Early Childhood}

There are parents' motives in providing gadgets for early childhood, namely:

\section{Because To Motive}

Motives arise because of previous experiences that each individual has experienced. This experience encourages someone to do things they think are better and more profitable for themselves while also making updates to be better in the future. This is also experienced by most parents who have previous experiences, so they have reasons to give gadgets to children, which include:

\section{a) To Please Children}

Parents play the most important role in the family. The responsibility of parents is very big, which makes 
a milestone in the family, especially in educating and guiding children [28]. This also applies in choosing and sorting out what is best for children. Parents should be able to act wisely in providing good facilities for children [29]. However, it is still often found that parents give things that are not ageappropriate, for example, such as giving gadgets to early childhood. The reason parents give gadgets is to obey the child's will so that the child is happy. Without realizing it, this parent's decision gives things that will negatively impact the child in the future, such as being lazy to study, reduced physical activity, more individual, aggressive, and so on.

This also happens to parents in the Kuncup Harapan Playgroup who want the best for their children in providing facilities. Parents obey their children's wishes because they do not want their children to be left behind with their friends. This happens because there is a reason, namely that parents in their childhood did not get what they wanted, sometimes they got angry and were not allowed to play anymore, and when playing only as spectators, their friends were playing with toys that were popular at that time. From the interview results, one of the subjects said that "giving gadgets to children because they want to fulfil their wishes so that they can feel gadgets like other friends. Do not be like me to get something when I'm an adult and work, or it can be said to try first to get what you want. At the moment, we work for who if not to please children".

Therefore, the experiences experienced can encourage someone to get something that was not obtained before. Unwittingly, these actions can be dangerous for those around them, such as giving gadgets to early childhood. Taking these actions indirectly, parents bring early childhood to a very insecure world. The negative impacts that arise are more dominant than the positive impacts of using gadgets for children. The role of parents should be as the main protector of the family who can make decisions in giving gadgets to early childhood [30].

\section{b) Keeping up with the Times}

The flow of globalization or the development of the times continues to experience the renewal that every individual on this earth cannot avoid. The development of the latest innovations changes every day, affecting a person's perspective on life [8], for example, using gadgets. For early childhood, the use of gadgets can be said to be unnecessary for continuing their lives. Parents give gadgets only so that children are not left behind and are gadget literate [31]. According to the interview results, the subject said, "giving early childhood gadgets so that they are not left behind with the times, because many of their friends have used gadgets. As parents, we do not want parenting styles for children that are not adapted to the development of their times. The parenting style of today's children should not be confused with the parenting style of our parents, which is currently considered more traditional."

From the results of the interview that there is a mindset of parents today has changed. They are more open to the times, so it is not wrong if most parents give gadgets to their children. Parents evidence this in the Kuncup Harapan Playgroup that most parents give their children their gadgets to easily operate the gadget even though they cannot read. They are very familiar with the symbols on gadgets such as symbols for youtube, WhatsApp, favourite games, etc. Parents allow this so that children can follow developments according to their times. The Kuncup Harapan Playgroup parents consider that the development of the times cannot be avoided, so giving gadgets is one way for children to keep up with the times because updates will occur in the digital world of the internet in the future.

\section{In Order Motive}

Motives arise because of the encouragement of values for actions taken for future goals. The goals from one person to another are different; this is the same as parents who form children with different goals. Parents play an important role in children's success because they cannot determine which direction to choose without them. As in giving gadgets to children, every parent has a reason tailored to determine the child's future direction. Because technology has become something big that will help human activities to be more complex in the future. Therefore parents have their judgment for children in using gadgets. Some of the value encouragement that makes the reason parents give gadgets to children, among others:

\section{a) As Social Status}

Currently, assessing a person's social status depends on what is used and shown on social media. Most people think that following the current trend is considered to have a high social stratum. With this assumption, people are competing to follow the updates that have been provided by the manufacturers, except for gadgets. Most people keep up with the development of gadgets; they think it is okay to lose much money for the sake of recognition from the community. The smallest unit in society is no exception, namely the family. Parents do not hesitate to provide the latest gadgets for their children. The decision of parents to give the latest gadgets cannot be separated from the influence of the association of parents' friends who only join in so that they are seen as having high social status [7].

From the interview results, one subject said that "Giving gadgets to early childhood with the aim of 
parents is considered to have the ability in terms of finance because early childhood is still not said to need to have a gadget. With this, parents look rich because they buy what they do not need. It is unavoidable that when parents get together, it can influence other parents to imitate those who buy their children the latest gadgets to make them look financially capable, even I personally am also affected by buying children's gadgets even though it is not important for children ". This makes some parents uncomfortable from the treatment that discriminates against someone based on wealth. This lifestyle makes a person a consumptive and bourgeois actor who will affect children's psychological and social development in society.

\section{b) So that children are more often at home}

Parents give gadgets to children with the aim that children are more often at home. Parents do not worry if the child is at home because they can easily supervise the child compared to outside. Especially for early childhood, because early childhood can be said to be very active in their movements and still do not fully understand what they are doing is dangerous or not. So that children feel at home, parents provide gadgets as a substitute for playing outside. From the interview results, one of the subjects said that "when the child is at home, I as a parent are not worried about something that is considered dangerous for the child. While at home, so that the child is calm, gadgets are given and do not interfere with my activities at home. Children play with gadgets for almost 3 hours, and even until homework is finished, children stay calm by playing with gadgets. During the Covid-19 pandemic, children learn online, so the duration of using gadgets is longer. If the child has experienced dependence in using gadgets without being balanced with other activities, the child's self pattern will change, both behaviorally, psychologically, socially and healthily [32].

Parents in the Kuncup Harapan Playgroup most children use gadgets at home for approximately 3-4 hours, even more, if the parents are busy. The purpose of giving gadgets to children to stay at home is indeed good, but the development of children requires support from the surrounding environment, such as peers, neighbours, relatives, and the community. This needs to be done for early childhood to improve development because, at an early age, it determines the success or failure of the child's maturity in facing the next life. Humans are social creatures who need other people to help themselves in meeting their needs [33]. If the child is confined to the house, they are safe and never feel challenged outside. So parents must manage their children's time both at home and outside the home.

\section{c) As a Play Tool}

The gadget is a technology that provides many features that many people can enjoy, ranging from children, adults, both male and female, school-aged children and the elderly. The gadget service feature makes it easy for people to help complete work; even most people use gadgets as entertainment, such as watching videos, playing social media and games on smartphones [34]. However, many gadget users, especially children, use gadgets to play games. This is following the results of an interview, one of the subjects said that "the purpose of children using gadgets is only to play games because there are so many choices of games on gadgets, so that it attracts children to play them, especially games that can be played online or offline. Like my child, I like COC and mobile legends games."

It is necessary for parents to pay attention to the time and type of play children play because children can imitate what they see and what they hear [35]. Parents in the Kuncup Harapan Playgroup are worried that their children have entered the addiction phase in playing games, so this is what makes parents report complaints during online learning. In the conditions of mothers and fathers working, the children are not controlled at home, unlike before the pandemic. At that time, the mother had not worked and is currently working because it helps the family economy, which is the impact of the Covid-19 pandemic. During this pandemic, one of the children from the Kuncup Harapan Playgroup was taken care of by his older brother, who also goes to online school. While at home, the older brother looks after his younger brother less than optimally because the school also spends more time playing games. Indirectly, the sister follows her brother, who plays games all day until one of the parents comes home from work. This is a problem that is often experienced by some families that impact the pandemic so that parents are less focused on supervising children playing gadgets. So parents must work together to overcome the problems and know what consequences they take that impact the child.

\subsection{The assistance of Parents in Using Gadgets for Early Childhood During the Covid-19 Pandemic}

There are ways for parents to assist early childhood in using gadgets, including:

\section{Limit Children's Time in Using Gadgets}

Most children's activities are carried out at home during the pandemic to avoid being infected with Covid-19. The teaching and learning process is carried out online or online, which requires media in the form of gadgets to facilitate the interaction 
between educators and students. This is also done by the Kuncup Harapan Playgroup, which implements online learning that has been carried out for more than a year. With online learning, parents cannot prevent children from using gadgets. However, children spend more time playing than their learning activities [36].

In early childhood, it can be said that children are active in doing physical activities, but this cannot be done because of existing limitations, so parents free their children to use gadgets so that they do not interfere with parents' activities at home. From the interview results, one of the subjects said, "so that children can stay at home quietly and do not ask for anything else, and I give gadgets to children until my work at home is finished". The use of gadgets for too long makes users addicted so that they have been staring at the screen for hours without realizing it. As a wise parent, of course, you can limit the use of gadgets for children. On average, parents of the Kuncup Harapan Playgroup limit their children's time using gadgets to around 3-4 hours. Diverting children, so they do not use gadgets too often, parents should replace gadgets with Educational Game Tools with this early childhood to improve their development. However, on the other hand, so that children do not lag with technology, there needs to be parental assistance in the use of gadgets. Because at this time, any activity is assisted by technological sophistication, so that parents are not left behind, parents can introduce gadgets to children who will become part of humans in the 4.0 era. During parenting activities during the pandemic, parents change their behaviour to be more concerned with children. They do not often use gadgets excessively, so this behaviour change is an example for parents not to use gadgets too often because children are great imitators who easily imitate other people's behaviour. Others [17]. Therefore, it is necessary to rearrange time management on the use of gadgets in the family.

\section{Selection of Age-appropriate Safe Content,}

Today's parents need the ability to choose good content for their children. This needs to be done because children can imitate what they watch. As Bandura's theory says, there is a parenting pattern based on symbolic models, namely models that come from parables, such as illustrated stories, television shows, videos, games and so on [37]. Therefore, it can be said that children are great imitators, so parents need to choose safe content according to the age of early childhood. The results from an interview from one of the parents said that "I choose watching content for children, but if the content is not suitable for the child and is replaced sometimes the child does not want to replace the content, such as the type of mobile legends game or the GTA youtube show which is known to have elements of violence inside it.
Children are now smarter than me, so they feel the need to learn. However, for now, I can divert children to choose safe content with children maybe by not filling in the internet data package, so children only play what can be played offline and cannot play and watch youtube online.

Parents of the Kuncup Harapan Playgroup feel that children's development of knowledge about gadgets is now smarter than their parents, not even for early childhood. For example, they were turning on internet data, changing wifi passwords, saving applications on the front screen, and so on where parents initially did not understand this. Therefore, parents need to continue to learn about the developments experienced by their children. The role of parents is not only as a child caretakers but also to educate, accompany, set an example, etc. The role of parents in the age of technology can be said to be very complex in being responsible to their children. Thus, parents need to update themselves on developments and do not be ashamed to learn by seeking information through online media, seminars, reading books and so on related to what is currently needed to support its development in the future.

\section{Balance the use of gadgets with children's activities}

The use of gadgets in early childhood for too long makes development not optimal because gadgets are used without any physical activity. One example of a smartphone in its use is just pressing buttons while sitting for hours. This is not good for early childhood because it will impact children in the future. If the use of gadgets is carried out for a long duration, the child will experience problems with eye health, then structurally the body will bend, and the strength in the body will weaken because there is no physical activity in it. So parents should be able to balance children with children's activities at home. One of the parents in the Kuncup Harapan Playgroup invites children during the Covid-19 pandemic with activities to help parents work at home, such as cooking together, cleaning the house together, caring for plants and so on. One of the results of an interview with the subject of the parent of the Kuncup Harapan Playgroup said, "we invite them to do physical activities at home so that children do not just play with gadgets. This is one way to distract children from being dependent on gadgets. Activities at home with children, such as cooking, drying clothes, sweeping, watering plants and others, the most important thing is that children do not just sit and stare at the screen, I feel sad when children can go to school face-to-face so that children can have activities with their peers".

The need for parental assistance for children to use gadgets, because the closest people to children are parents. Child development is the responsibility of parents. So for optimal development, invite children 
to play physical activities that can help children explore knowledge, such as playing lego, jumping rope, playing synthetic sand, sports, role-playing, and other educational games. Early childhood is a child of playing age, and they like playing activities. Parents must choose and sort out children's games according to age [38]. Most of the parents of Kuncup Harapan Playgroup have limited the use of gadgets for too long. Then when children are playing with gadgets, parental assistance is needed and limit the duration of using them. The way for parents of Kuncup Harapan Playgroup is to prevent children from playing with gadgets excessively, namely with other activities, so that children forget the gadgets they previously played. By establishing communication between parents and children, they can provide a good understanding so that they understand why parents limit their activities in playing gadgets. The parents of Kuncup Harapan Playgroup provide an understanding that children can help their parents work at home. For children to be physically active, the parents of Kuncup Harapan Playgroup provide light work for children, then interspersed with the meaning of learning in it, so that children can understand what they are doing and feel happy to repeat the activity. So that children can be regular in activities at home, parents must make a schedule of children's activities. Several parents of the Kuncup Harapan Playgroup have made a schedule. They make a weekly schedule that includes learning activities playing, bathing, eating, sleeping, reading the Koran, helping parents, and so on. Set Rules for Using Gadgets for Children

For early childhood, playing is a very fun thing, not to mention playing with gadgets. Sometimes children forget when they have played gadgets and parents tell them to stop there must be dramas of quarrels between children and parents. This is by the results of an interview from one of the subjects of the parent, Kuncup Harapan Playgroup, who said that "My child and I often fight because the child does not want to do what I say. Then when you play gadgets, it does not stop." From these problems, parents should be able to build communication with their children. When children play new gadgets, parents should understand in a calm and not chaotic situation. Invite the child to communicate, tell the child well, then make definite rules in writing. The rules for using gadgets are also made, such as the duration of using gadgets, for example, a maximum of one hour, being allowed to play with gadgets after finishing studying, then determining when children use gadgets, for example when a day off is Sunday or twice a week on different days. Parents should participate in carrying out the rules so that children obey these rules, such as parents not playing gadgets for too long in front of children. Set a good example for children and make time for children by playing together. With this, the child is at home during the Covid-19 pandemic. The child does not feel bored because some schedules and rules must be obeyed as a form of child responsibility.

Kucup Harapan Playgroup parents also do this. Most parents make written rules for their children and rules on the use of gadgets. Nevertheless, sometimes this rule does not work well because some conditions require children to use gadgets longer because of busy parents. Parents provide gadgets without them accompanying them to prevent children from crying, bored by themselves and so that they do not leave the house. This is under the results of the parent interview of the Kuncup Harapan Playgroup "I have made rules for using gadgets, but sometimes the rules do not apply if I am busy. Instead of children bothering me, gadgets are given to children until I finish with my work". From these problems, parents should continue to be consistent in giving rules because children can judge the rules set by parents. Parents are needed in managing time management between busyness and caring for children. It is hoped that children do not become victims of the negative impacts of using gadgets.

\section{Parents Adapt To The Times}

The way of parenting in the past and now is very different. In the past, parents in educating more directed towards authoritarian parenting, but this does not apply to today's child care patterns. Parents today are more complex in educating children. If bad parenting is given to children, it will be fatal in children's lives in the future, such as children who rebel, act criminally, and so on. So parents need to be able to adapt to the times [39]. The interview results from the subject said, "I always update myself to keep learning, so I do not get left behind with my child. I am afraid if I do not adjust my child, I do not know what gadgets to use for my child". Another opinion from the parent subject of the Kuncup Harapan Playgroup said that "as parents, we need to be careful in educating because nowadays children can easily obtain information, it is necessary as parents to enter the world of children, especially for early childhood by creating a child account provided by the google platform". So parents need to have broad insight by continuing to learn. Because learning knows no age, gender, occupation and so on, it should be emphasized again that learning is in school and can be done anywhere, anytime, with whom and with various learning resources. Parents need to seek information and change the traditional mindset to a modern mindset so that parents are not technologically savvy [40].

Parents in the Kuncup Harapan Playgroup mostly have social media on Whatsapp, Facebook, Instagram, telegram, etc. The ownership of social media proves that parents have been able to adapt to the current 
developments. However, gadgets are only limited to uploading photos and videos, writing social media statuses, making friends, and buying goods online (shop). However, parents rarely use Google, a search engine with much information in it. So it is necessary to make it easier for parents to get knowledge about the internet that is friendly for early childhood through socialization, discussion, reading materials, and so on. From several parental complaints during the Covid-19 pandemic, the Kuncup Harapan Playgroup institution provides services to parents in an e-parenting application that contains information related to children. It is hoped that with re-parenting, parents can be well literate to know how to accompany children on the internet.

From several problems parents face in the Kuncup Harapan Playgroup while studying from home, the Kuncup Harapan Playgroup institution provides parenting services, namely online consultations. A form of collaboration between parents and educators for the Kuncup Harapan Playgroup during the current pandemic through parenting programs, including,

1) Involvement in learning at home, during the current pandemic Kuncup Harapan Playgroup invites parents to learn and play at home with their children. Parents here act as substitute teachers at school by accompanying each child's learning activities, including gadgets. Educators at Kuncup Harapan Playgroup provide direction to parents through parenting activities to limit children's use of gadgets. The method that has been given is in the form of providing educational games so that children forget to use gadgets. Then after participating in parenting activities several times during the pandemic, parents' insight into parenting patterns is increasingly open so that parents' changes in using gadgets are controlled and invites children to play more by aspects of child development. This needs to be done for the readiness and success of children in the future.

2) Communication, during the pandemic, humans have limitations to meeting each other to avoid the spread of Covid-19. This limitation does not prevent parents from communicating with the educators of the Kuncup Harapan Playgroup. Forms of communication between parents and educators with interpersonal and group approach through WhatsApp and google meet. Interpersonal communication is carried out every day from parents to educators in providing information on learning activities or consulting obstacles in parenting at home. This communication activity with educators is carried out every two weeks; parents communicate interpersonally to early childhood psychologists to discuss barriers to parenting while children study at home. In addition, there is group communication carried out by the Play Group through activities held once a month, namely with several materials, such as coaching for learning assistance during learning at home, solutions to parenting barriers, how to limit children playing gadgets and training to make Simple educational play equipment from used materials or items at home attended by experts in the field of early childhood education, through group discussion activities parents can understand how parenting and become a child's teacher while at home. Intense communication makes parents feel cared for by the school so that parents can find reliable information according to experts in their fields

3) Volunteers, Play Group parents are invited to participate in social activities to share through charity activities for those affected by the Covid-19 pandemic during pandemic. Through this activity, parents, educators, and children are invited to work together to help others in need, starting with the closest parties to the school community and then the orphanage. With this activity, the child can grow a sense of caring and not disobey the mother when given advice. In addition to these activities, parents of the Kuncup Harapan Playgroup are invited and willing to accompany children to study at home and play an active role in parenting, especially in assisting in using gadgets.

4) Decision-making in children's education, parents are invited to be directly involved in planning and implementing children's learning. Thus parents can understand how to teach children, thereby fostering parental creativity in making new things so that children do not feel bored and do not ask for gadgets as toys for themselves. Thus, parents are invited to make decisions by their children's learning needs, especially during the pandemic.

In addition, the institution also provides digital literacy services in the form of an e-parenting application that aims to help parents relate to their children. The e-parenting application makes it easier for parents to get information without searching first, and most parents do not know whether the source read is a trusted reference. In e-parenting, the reference sources obtained are guaranteed to be reliable because they are taken from the latest journal sources. With the development of digital literacy, it is hoped that parents can be more knowledgeable and keep up with the times, especially creating a child-friendly internet at home. The e-parenting application is one of the efforts of parents to be literate during the Covid-19 pandemic to make it easier to accompany children, especially in the use of gadgets for early childhood.

Children's assistance in using gadgets is needed because the negative impacts are more dominant than the positive ones. Parents should be able to adapt to the times and continue to be willing to learn new things. The goal is to assist children in using gadgets to be controlled in using gadgets. Because early childhood is the age of children who are developing 
very rapidly, it takes a good stimulus from people around so that children can wisely determine the direction to be taken, both now and in the future. During the current Covid-19 pandemic, which has been more than a year, parents still find it difficult to accompany their children to study online due to the lack of parental knowledge to become educators at home, especially learning through gadgets where children cannot concentrate in learning but prefer to play gadgets.

\section{CONCLUSION}

Parents in the Kuncup Harapan Playgroup have used several ways in assisting children in using gadgets, namely limiting children's time in using gadgets, choosing safe content according to the child's age, balancing the use of gadgets with children's activities, setting rules for using gadgets for children and parents need to adapt to the development of this era to assist children in using gadgets. However, some female parents (mothers) cannot fully supervise their children at home for work reasons due to the impact of the Covid-19 pandemic. With this, children are given gadgets while their parents are working, so they do not interfere until children play with gadgets for more than 3-4 hours which weakens their physical and psychological abilities. This problem creates an opportunity for KB Kuncup Harapan to collaborate with parents through parenting programs held by the school during the Covid-19 pandemic, namely learning engagement activities at home, communication, volunteering, and decision-making for children's education, as well as providing parents with digital literacy reduce the negative impact of using gadgets through re-parenting applications.

\section{ACKNOWLEDGMENTS}

Acknowledgements are given to the Director and Head of the Postgraduate Education Study Program at the State University of Surabaya to provide this research opportunity. Parents and the Kuncup Harapan Playgroup (KB) have helped and succeeded in researching the negative impact of using gadgets for early childhood during the Covid-19 pandemic.

\section{REFERENCES}

[1] C.-C. Lai, T.-P. Shih, W.-C. Ko, H.-J. Tang, and P.-R. Hsueh, "Severe acute respiratory syndrome coronavirus 2 (SARS-CoV-2) and coronavirus disease-2019 (COVID-19): The epidemic and the challenges," Int. J. Antimicrob. Agents, vol. 55, no. 3, p. 105924, 2020, doi: 10.1016/j.ijantimicag.2020.105924.

[2] C.-19 Satgas, "Data Sebaran Pasien Positif Covid-19 di Indonesia,” Jakarta, 2021. [Online].
Available: covid19.go.id.

[3] A.D. Cahyani, "Sinergi antara Orang Tua dan Pendidik dalam Pendampingan Belajar Anak selama Pandemi Covid-19," Obs. J. Pendidik. Anak Usia Dini, vol. 6, no. 2, 2021, doi: 10.31004/obsesi.v6i1.1130.

[4] R. Mellynia, A. Trisiana, N.N. Viyani, F. Safitri, N.T. Handayani, and I.N. Sholehah, "Bersatu Melawan Covid-19 dengan Hidup Sehat dalam Perspektif Pendidikan Kewarnegaraan," J. Glob. Citiz. J. Ilm. Kaji. Pendidik. Kewarganegaraan, vol. 9, no. 1, pp. 24-38, 2020, doi: 10.33061/jgz.v9i1.3882.

[5] N.R. Yunus and A. Rezki, "Kebijakan pemberlakuan lock down sebagai antisipasi penyebaran corona virus Covid-19," 2020, doi: 10.15408/sjsbs.v7i3.15083.

[6] M. Taufik and A. Armansyah, "Eksistensi Pelaku Usaha Sektor Informal Offline dan Online di Tengah," Publikauma J. Adm. Publik Univ. Medan Area, vol. 9, no. 1, pp. 57-66, 2021, doi: 10.31289/publika.v9i1.4846.

[7] Y.S. Hijriyani and R. Astuti, "Penggunaan Gadget pada Anak Usia Dini dalam Menghadapi Era Revolusi Industri 4.0," ThufuLA J. Inov. Pendidik. Guru Raudhatul Athfal, vol. 8, no. 1, pp. 15-28, 2020.

[8] M. Ngafifi, "Kemajuan teknologi dan pola hidup manusia dalam perspektif sosial budaya," $J$. Pembang. Pendidik. Fondasi dan Apl., vol. 2, no. 1, 2014, doi: 10.21831/jppfa.v2i1.2616.

[9] I. Istianah and S. Wahyuningsih, "The Hadith Digitization in Millennial Era: A Study at Center for Hadith Studies, Indonesia," QIJIS (Qudus Int. J. Islam. Stud., vol. 7, no. 1, pp. 25-44, 2019, doi: 10.21043/qijis.v7i1.4900.

[10] J. Schlechtendahl, M. Keinert, F. Kretschmer, A. Lechler, and A. Verl, "Making existing production systems Industry 4.0-ready," Prod. Eng., vol. 9, no. 1, pp. 143-148, 2015, doi: 10.1007/s11740-014-0586-3.

[11] D. S. Junida, "Kecanduan Online Anak Usia Dini," Walasuji, vol. 10, no. 1, pp. 57-68, 2019, doi: 10.36869/wjsb.v10i1.39.

[12] I.T.M. Daeng, N.N. Mewengkang, and E. R. Kalesaran, "Penggunaan smartphone dalam menunjang aktivitas perkuliahan oleh mahasiswa FISPOL UNSRAT Manado," Acta Diurna Komun., vol. 6, no. 1, 2017.

[13] I. Jones and Y. Park, "Virtual worlds: Young 
children using the internet," in Young Children and Families in the Information Age, Springer, 2015, pp. 3-13.

[14] N. Sahriana and Y. K. S. Pranoto, "Perception of Preschoolers (3-7 years) on Usage of YouTube in Semarang," in 4th International Conference on Early Childhood Education. Semarang Early Childhood Research and Education Talks (SECRET 2018), 2018, pp. 27-33, DOI: 10.2991/secret-18.2018.5.

[15] C. Rowan, “Unplug-Don't drug: A critical look at the influence of technology on child behavior with an alternative way of responding other than evaluation and drugging," Ethical Hum. Psychol. Psychiatry, vol. 12, no. 1, pp. 60-68, 2010, DOI: 10.1891/1559-4343.12.1.60.

[16] T. Alia and I. Irwansyah, "Pendampingan orang tua pada anak usia dini dalam penggunaan teknologi digital [parent mentoring of young children in the use of digital technology]," Polyglot J. Ilm., vol. 14, no. 1, pp. 65-78, 2018, doi: 10.19166/pji.v14i1.639.

[17] W. W. Setyorini and N. Kurnaedi, "Pentingnya Figur Orang Tua dalam Pengasuhan Anak," 2018.

[18] U. Rahman, "Karakteristik perkembangan anak usia dini," Lentera Pendidik. J. Ilmu Tarb. dan Kegur., vol. 12, no. 1, pp. 46-57, 2009, doi: 10.24252/lp.2009v12n1a4.

[19] S. Livingstone, K. Ólafsson, E. J. Helsper, F. Lupiáñez-Villanueva, G. A. Veltri, and F. Folkvord, "Maximizing opportunities and minimizing risks for children online: The role of digital skills in emerging strategies of parental mediation," J. Commun., vol. 67, no. 1, pp. 82105, 2017, DOI: 10.1111/jcom.12277.

[20] N. Sahriana, "Pentingnya Peran Orang Tua Dalam Penggunaan Gadget Pada Anak Usia Dini," J. Smart PAUD, vol. 2, no. 1, pp. 60-66, 2019, doi: 10.36709/jspaud.v2i1.5922.

[21] D. Sudjana, "Manajemen Program Pendidikan: Untuk Pendidikan Nonformal dan Pengembangan Sumber Daya Manusia," Bandung Falah Prod., 2004.

[22] H. Wahy, "Keluarga Sebagai Basis Pendidikan Pertama dan Utama," J. Ilm. Didakt., vol. 12, no. 2, 2012, doi: 10.22373/jid.v12i2.451.

[23] H. Baharuddin, "Parenting Styles During the Covid-19 Pandemic: A Conception of Islamic Family Law," Al-Bayyinah, vol. 5, no. 1, pp. 1328, 2021, DOI: 10.35673/al-bayyinah.v5i1.788.
[24] A. Suprijono, "Pengaruh Live Model, Symbolic Model, Dan Verbal Description Model Terhadap Pemahaman Siswa SMA Tentang Konsep Sosiologi," J. Ilmu Pendidik., vol. 16, no. 3, 2016, doi: 10.17977/jip.v16i3.2566.

[25] M. M. Poloma, Sosiologi Kontemporer. Jakarta: Raja Wali, 2004.

[26] E. Rianti, "Kadisdik: Awasi Penggunaan Gadget pada Anak," Republika, Jakarta, Feb. 2021.

[27] S. Suryameng, "Pendampingan Dialogis Orangtua Dalam Penggunaan Gadget Pada Anak Usia Dini," Dunia Anak J. Pendidik. Anak Usia Dini, vol. 2, no. 2, pp. 40-49, 2019, doi: 10.31932/jpaud.v2i2.764.

[28] E. Ruli, "Tugas dan Peran Orang Tua dalam Mendidik Anak," J. Edukasi Nonform., vol. 1, no. 2, pp. 143-146, 2020.

[29] Q. Qomaruddin, "Pendampingan Orangtua terhadap Pendidikan Anak," Cendekia, vol. 3, no. 1, p. 268443, 2017.

[30] Y. Yuliejantiningsih, "The implementation of online learning in early childhood education during the Covid-19 Pandemic," J. Pendidik. Usia Dini, vol. 14, no. 2, pp. 247-261, 2020, doi: 10.21009/JPUD.142.04.

[31] S. R. Mayang, "Motif Orang Tua Memberikan Gadget Kepada Anak Studi Kasus Desa Kampung Baru Kecamatan Kayu Aro Barat Kabupaten Kerinci Propinsi Jambi.” STKIP PGRI Sumbar, 2015.

[32] M. Munisa, "Pengaruh Penggunaan Gadget Terhadap Interaksi Sosial Anak Usia Dini Di TK Panca Budi Medan,” J. Abdi Ilmu, vol. 13, no. 1, pp. 102-114, 2020.

[33] E. N. Inah, "Peranan komunikasi dalam pendidikan," Al-TA'DIB J. Kaji. Ilmu Kependidikan, vol. 6, no. 1, pp. 176-188, 2013.

[34] D. Munir, M. D. Himpong, and S. M. H. Thaib, "Dampak Gadget dalam Memotivasi Peningkatan Prestasi Belajar Mahasiswa Prodi Ilmu Perpustakaan FISIP UNSRAT," ACTA DIURNA Komun., vol. 2, no. 1, 2020.

[35] W. A. Puspita, "Pendidik Pendidikan Anak Usia Dini (Paud) Sebagai Model Perilaku Anak Usia Dini," J. Ilm. Visi, vol. 5, no. 2, pp. 209-215, 2010, doi: 10.21009/JIV.0502.9.

[36] O. I. Handarini and S. S. Wulandari, "Pembelajaran Daring Sebagai Upaya Study From Home (SFH) Selama Pandemi Covid 19," J. Pendidik. Adm. Perkantoran, vol. 8, no. 3, pp. 496-503, 2020. 
[37] N. Nurfaizah and R. Romlah, "Keberhasilan Mengembangkan Sosial AUD Melalui Teknik Modeling," Al-Athfaal J. Ilm. Pendidik. Anak Usia Dini, vol. 3, no. 1, pp. 56-68, 2020, doi: 10.24042/ajipaud.v3i1.6654.

[38] D. Murtiningsih, "Peran Orangtua dalam Kegiatan Bermain Anak Usia Dini (4-6 Tahun) di Rumah (Studi Pada RT. 05/07 Kelurahan Gegerkalong Kota Bandung)," J. Pendidik. Luar Sekol., vol. 9, no. 2, 2013.

[39] J. Andriyani, "Korelasi peran keluarga terhadap penyesuaian diri remaja," J. Al-Bayan Media Kaji. dan Pengemb. Ilmu Dakwah, vol. 22, no. 2, 2016, doi: 10.22373/albayan.v22i34.878.

[40] N. S. R. Rais, M. M. J. DIEN, and A. Y. DIEN, "Kemajuan teknologi informasi berdampak pada generalisasi unsur sosial budaya bagi generasi milenial," J. Mozaik, vol. 10, no. 2, pp. 61-71, 2018. 